\title{
СЕМИОТИЧЕСКАЯ МИМИКРИЯ В СИНКРЕТИЧЕСКИХ РЕЛИГИОЗНЫХ ОРГАНИЗАЦИЯХ НА ПРИМЕРЕ «МИХАЙЛОВСКОЙ ОБИТЕЛИ» Г. ПЕНЗЫ
}

\section{SEMIOTIC MIMICRY IN SYNCRETIC RELIGIOUS ORGANIZATIONS ON THE EXAMPLE OF THE ST. MICHAEL'S MONASTERY IN PENZA \\ M. Fedyashkin (hieromonk Tikhon)}

Summary: The article describes the author's personal experience in the study of semantic mimicry in syncretic religious organizations, gives an example of the study of mimicry in the Mikhailovsky Monastery, operating on the territory of the Penza diocese, and the peculiarities of adapting this organization to the conditions of existence in different periods of its activity. An assessment of the activities of such structures for the life of society is given, and a justification for the definition of such organizations as extremist. In the context of the study, the author proposes a deeper study of extremist pseudo-religious organizations in order to develop adequate social measures to counter this phenomenon in society.

Keywords: semantic mimicry, syncretic religious organizations, religious extremism, Mikhailovskaya monastery, marginal religious movements.
Федяшкин Михаил Владимирович (иеромонах Тихон)

Священнослужитель, Русская Православная Церковь Пензенской епархии; старший преподаватель, Пензенская Православная Духовная семинария; судья, коллегия церковного епархиального суда Пензенской епархии o_tihon@mail.ru

Аннотация: В статье излагается личный опыт автора в исследовании семантической мимикрии в синкретических религиозных организациях, приводится пример исследования мимикрии в действовавшей на территории Пензенской епархии «Михайловской обители» и особенности приспособления этой организации к условиям существования в разные периоды ее деятельности. Дается оценка деятельности подобных структур для жизни общества, и обоснование для дефиниции таких организаций как экстремистских. В контексте проведенного исследования, автором предлагается более глубокое изучение псевдо-религиозных организаций экстремистской направленности с целью выработки адекватных общественных мер противодействия этому явлению в обществе.

Ключевые слова: семантическая мимикрия, синкретические религиозные организации, религиозный экстремизм, Михайловская обитель, маргинальные религиозные течения.

Феномен мимикрии синкретических религиозных объединений, с одной стороны, является необычным явлением, поскольку, по сути своей, религиозные догмы, в своем ортодоксальном большинстве, исключают всяческий обман в вероучении и декларируют его как отступление от веры, попросту говоря - грех. С другой стороны, если мы говорим об общинах, которые откололись от среды общепризнанной, глобальной религиозной организации, то перед ними стоит задача, как минимум - выживания, а в идеале - роста и распространения. А этого достичь можно, лишь скрыв свою маргинализацию от потенциальных адептов. По крайней мере, на первоначальном этапе. Ведь, синкретические общины прибегают к увеличению своей численности, в первую очередь, за счет приверженцев той религии, от которой они откололись. Но фундаментальные религии отличаются консервативностью и отступление от устоявшихся догм и порядка в них - неприемлемо. Поэтому, на каком-то этапе своего развития, маргинальные религиозные общины стараются отождествить себя с фундаментальной религией, декларируя, что она исповедуется ими наиболее правильно. Конечно, это, если говорить честно обман, то, что всегда и в уме этих людей тоже, считалось большим грехом. Но феномен - он потому и феномен, 
что выбивается из рамок общечеловеческого мировоззрения. В первую очередь маргиналы обманули самих себя, последуя искривленному сознанию в собственной мысли. Они объявили отступниками всех остальных, себя же - защитниками веры и единственными борцами за правду. Этим можно и объяснить и оправдать фанатизм и экстремизм их учений.

Говоря в целом о мимикрии синкретических религиозных общин, думается, будет правильным для этого явления ввести понятие - семиотическая мимикрия, поскольку именно внешние черты, систему организации, культовую часть и многое другое, что составляет эстетическую часть религии, синкретическая община копирует у фундаментальной религиозной организации. По сути своей, семиотическая мимикрия нацелена на контингент, который далек в исповедании своих религиозных убеждений от глубокого догматического познания, и оценка деятельности религиозной группы выносится индивидуумом исходя из эстетического восприятия жизни общины, при полной невозможности критической теологической оценки ее вероучения [1, с. 139-140]. Такой подход к деятельности религиозных организаций - наиболее распространен, тем более, что всеобщая нелюбовь к изучению догматики свойственна последователям большинства фундаментальных вероучений. При этом, говоря о синкретизме, именно принятие в свое вероучение элементов, неприемлемых для фундаментальной религиозной структуры, и являющихся несовместимыми с ее догматикой и принципиальным устроением, в синкретических общинах выступает главным принципом, который на первоначальном этапе должен быть тщательно замаскирован. Это - аллогизм, но он вполне объясним: догматика ортодоксальных вероучений весьма сложна и полемична. Человеческий разум желает выйти из этой полемики в зону комфорта, которую и составляют синкретические, облегчающие принятие и понимание, учения. Сложен догмат о Троице - веруй проще. Под этим лозунгом прошли антитринитарные учения древности. Сегодня и не об этом речь. Сложно общество - объяви его врагом и веруй в то, что делает тебя выше его. Веруй, что ты лучше, осведомленнее, благочестивее остальных, и ты - спасен. Соблазнительная приманка современности. Но здесь - опять эти же принципы эстетического восприятия религии, выраженные в словесной характеристике организации: «Церковь» или «секта». Невозможно создать религиозную общину, назвав ее «сектой», никто не захочет быть ее последователем. Поэтому и важно, не имея признаков и организационной структуры «Церкви», внешне изобразить ее, и назваться ее именем.

Здесь же необходимо отметить, что явление семиотической мимикрии - наиболее распространенное явление, возникающее при столкновении маргинализованной части религиозного общества с ортодоксаль- ной Церковью, и, в случае образования раскола, при котором, обычно, маргиналы лишаются своего положения в религиозной организации, мимикрия становится фактором самоубеждения их в правоте своих действий, позволяя вести привычный образ жизни и деятельности (например - это касается священнослужителей, извергнутых из сана, либо получивших его незаконно, но продолжающих совершать привычные священнодействия, несмотря не то, что для их совершения они уже не имеют канонической церковной связи).

В свете распространения в наше время множества псевдо-православных организаций, коим в большой степени присуща семиотическая мимикрия, видится логичным изучить этот феномен на конкретном примере.

Очень ярким примером семиотической мимикрии является маргинальная псевдо-православная община, действующая в Пензенской области, известная в определенных кругах как «община старца Алексия», или «Михайловская обитель», по названию храма в честь архистратига Михаила, который был построен в центре «монастыря». Автору статьи в 2009-2010 годах пришлось состоять в межведомственной группе Правительства Пензенской области по вопросу деятельности этой организации, и выступать в качестве эксперта по оценке ее деятельности. Поэтому, в области заявленной темы, семиотической мимикрии псевдо-православных религиозных организаций, будут использованы данные собственной работы, полученные путем изучения литературы, издаваемой этой организацией и опросом большого количества людей, имевших отношение к «общине».

Эта группа зародилась в г. Пензе в 80-х годах, когда уроженец с. Лунино Пензенской области, Михаил Шумилин (будущий «старец Алексий») переехал в город. Сам Михаил с детства был разбит параличом, не передвигался без посторонней помощи, не мог внятно говорить, но обрел любовь пензенцев своей молитвенностью. Его охотно брали многие верующие к себе в дома, и вместе с ним посещали пензенские храмы. Так образовался круг почитателей. Все было бы хорошо, но в начале 90-х годов в среде почитателей образуется активная группа, которая приобретает для инвалида дом, организует «прием» богомольцев, для перевода невнятной речи «старца» находятся и «толковники». И на этой стадии еще нет образования отдельной общины, это было явление, которое всегда характерно для Православия: люди, имеющие какой-либо дар рассуждения, мудрости, либо просто добрые люди, искренно исповедующие веру, всегда привлекали к себе других верующих, которым хотелось на живом примере научиться практике православного благочестия. Имя Михаила Шумилина было известно всему городу, он пользовался всеобщим уважением, в том числе и правящего архиерея Пензы - архиепископа Серафима (Тихонова). Но через некоторое время, как ча- 
сто это и бывает, нашлись люди, которые увидели в том, что дом «старца» всегда полон богомольцами - источник большого дохода, если все это дело развернуть в нужное русло. С этого момента, незаметно для окружающих, начинается работа по организации «общины». Инвалид Михаил Шумилин, с рождения и до смерти прикованный к инвалидному креслу - не мог быть клириком Православной Церкви, и, правдой будет сказать, что самого его это вполне устраивало. Но для развития общины этого было мало. Нужен был священный сан, высокий монашеский чин. Для пущего авторитета Михаила Шумилина облекают в схиму, нарекая новое имя - Алексий, и посвящают в сан пресвитера в известной раскольнической «Церкви» Филарета Денисенко, бывшего митрополита Киевского и всея Украины РПЦ, лишенного сана в 1992 году и отлученного от Церкви Собором архиереев в 1997г. Там же принимает священство и несколько из приближенных. С этого момента община разрывает связь с официальной Церковью и, будучи уже финансово обеспеченной, организует свою «обитель», построив комплекс зданий напротив Успенского храма пос. Победа в пригороде Пензы. Как относился к этому сам Михаил - сказать сложно. Есть фотоматериалы, где он в священнических ризах преподает подобие благословения, есть описание его «рукоположения» и «богослужений», совершаемых им. Но сколько здесь правды - одному Богу известно. По своей кончине, он завещал похоронить себя не в «общине», а у православного Успенского храма, что и было исполнено. Так что глубина духовной жизни этой личности так и останется загадкой. Факты же выводят нас к иным людям - его ближайшим адептам, создавшим «Михайловскую обитель».

Автору этих строк приходилось беседовать с теми, кто приезжал в «обитель старца». Семиотическая мимикрия, которая «разыгрывала карту» эстетического тождества с Православной Церковью была выстроена самым тщательнейшим образом. Никто из паломников, и даже людей, работающих в «обители», даже не знал о том, что имеет дело с самосвятами. Это были обычные прихожане разных храмов Русской Православной Церкви. Как выяснилось, «священнослужители», полностью копируя богослужение, возносят за ними имена и Патриарха и правящего Пензенского архиерея. Это обычно является большим камнем преткновения для раскольнических сообществ, поскольку является принципиальным признаком канонической принадлежности организации, но приближенные «старца Алексия» кроме того, что желали самостоятельности от какой-либо епархии, не желали терять своих адептов, которые явно не пришли бы к ним, узнав, откуда они получили свое ложное «посвящение». В связи с этим они и пошли на этот шаг, что лишний раз свидетельствует о беспринципности подобных маргинальных течений. Поэтому эта «обитель» и ее «филиалы», а таких храмовых и полумонастырских комплексов по области было несколько, называли себя домашними церковками, которые не входят в состав епархии лишь в силу своей «домашности». Часто, в качестве аргумента о самостоятельности, приводился довод, что епархия будет собирать с них большой налог, а также вмешиваться во внутренние дела, что преподносилось как очень неполезное действие. Вместе с этим, антураж был полностью соблюден: поминовение Патриарха и Пензенского архиерея за богослужениями создавало крепкую иллюзию связи раскольников с канонической Церковью. Таким образом, семиотическая мимикрия данной организации позволила не просто создать общину с большим числом адептов, но и незаметно вписаться в структуру самой епархии, ведь тем, кто посещал «Михайловскую обитель» не приходило в голову, что они стали адептами секты. Из других городов организовывались паломнические маршруты, и приезжающие также не подозревали, что «обитель» - самозваная. Эти люди не просто становились последователями культа «старца», они привносили информацию, влагаемую в их уши - в самые недра Првославной Церкви, распространяли тайно, как было заведено, литературу «Михайловской обители». Таким образом, культ обрастал коммерцией. Фото Михаила Шумилина и книги о нем стали распространяться за пределами Пензенской епархии в огромных количествах, а ложные грифы о благословении разными архиереями, которые и не подозревали об этом, позволяли сектантским книгам занимать полки весьма уважаемых издательских магазинов. Автор этой статьи встречал эти книги на полках издательства и Троице-Сергиевой Лавры и иных известных книжных магазинов Москвы.

Закономерно может возникнуть вопрос о том, зачем мы затронули эту «тихую обитель» в контексте исследования семиотической мимикрии. Ведь, по сути, это внутрицерковное дело, не затрагивающее общество. В нашей стране существует свобода вероисповедания, а значит, и подобные «общины», тихо и мирно проводящие свою жизнь, имеют право на существование. Мало ли противоречивых мнений в Православной Церкви о разных предметах. Но дело в том, что подобный обман, кажущийся вполне безобидным для обывателя, несет в себе скрытую общественную опасность. Ведь эта мимикрия под добродетельных и истинных пастырей, позволяла им внушать своей, а по факту - не своей, а всероссийской пастве те вещи, которые послужили основанием признать «общину» не просто синкретической религиозной группой, а экстремистской организацией: отказ от государственных документов, удостоверяющих личность, призыв к недоверию официальным священнослужителям, пропаганду недоверия власти, а также гражданского неповиновения и т.п. Члены обители вымогали у граждан деньги, убеждая их переселиться в пос. Победа, убеждали отдавать свои дома и землю, а самим переселяться в обитель, где их ждало нищенское существование без прав и надежды на будущее. Были заведены уголовные дела, а городским судом было вы- 
несено решение о ликвидации нескольких объектов недвижимости, построенных на территории «обители» без надлежащих прав. В адрес судебных приставов посыпались угрозы, в которых жители «тихой общинки» обещали поднять в населенном пункте бунт и 200 человек положить под колеса техники, которая приедет сносить эти здания. Тогда судебная власть отступила. Стало ясным, что «Михайловская обитель» превратилась в горячую точку на карте области. Такое противостояние продолжалось несколько лет. После этого миссионерскому отделу Пензенской епархии удалось убедить жителей города и области в нелегитимности этой организации, а судебным приставам - ликвидировать незаконные объекты. Сейчас община практически прекратила свое существование.

Подобные примеры - не единичны. Такое, пожалуй, можно найти в каждой области. Общее здесь одно - притворяясь истинными служителями Бога, люди работают против общества - совершают мошеннические действия, распространяют пропаганду антиобщественных и антицерковных идей, подрывая авторитет Церкви и ее вероучения, и наполняя умы верующих сомнительным суррогатом, приводя некоторых в агрессивные псевдоправославные секты, некоторых оставляя без жилья и средств к существованию, а некоторых и вовсе - к лишению себя жизни.

Таким образом, семиотическая мимикрия в псевдо-православных религиозных объединениях является весьма многогранным и интересным с точки зрения религиоведения, этики, права - феноменом, который являет собой широкое поле для исследования в более глубоком формате явления псевдо-религиозного экстремизма как рефлексии общественных проблем в обществе. К сожалению, заметный иногда поверхностный подход к этому вопросу не позволяет объективно и глубоко, а значит - правильно оценить этот опасный процесс. Тем не менее, глубокий анализ проявлений экстремизма и синкретизма в религии может дать объективные данные, которые помогут в процессе борьбы с этим негативным явлением. В данном исследовании рассмотрен единственный пример развития современного религиозного синкретического сообщества и технологии его влияния на социум. Думается, что сопоставление ряда таких примеров, и глубокое и беспристрастное их исследование, позволит выработать систему, которая бы могла бы противодействовать подобным процессам в обществе и остановить их негативное влияние в условиях бытия современного мира.

\section{ЛИТЕРАТУРА}

1. В.Ю. Лебедев, А.М. Прилуцкий Семиотическая мимикрия и функционирование религиозных знаковых систем: постановка проблемы. // Вестник ТеГу. Серия «ФИЛОСОФИЯ», 2018, №1 